JURNAL MAKSIPRENEUR, Vol. VII, No. 1, Desember 2017, hal. 94-106

\title{
ANALISIS PENGARUH PELATIHAN SELF- LEADERSHIP DAN MOTIVASI BERPRESTASI TERHADAP KINERJA KEPALA DESA DI KABUPATEN GUNUNG KIDUL YOGYAKARTA
}

\author{
Muhamad Ali Sukrajap \\ Universitas Proklamasi 45, Yogyakarta \\ Dewi Handayani Harahap \\ Universitas Proklamasi 45, Yogyakarta \\ Korespondensi penulis: dhou.personal@gmail.com
}

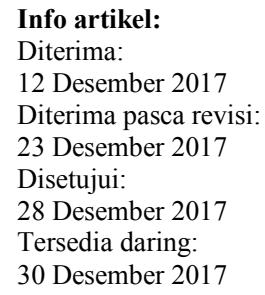

Abstract: Ministry of Rural Regulation No. 6 Year 2014 about rural area said that the rural area has grown so it needs to be protected and empowered to be strong, advanced, independent, and democratic area, so as to create a strong foundation to implement governance and development towards a fair, affluent, and prosperous society. In fact, the equitable distribution of infrastructure and suprastructure is not evenly distributed in each village.

This can be seen from the Rural Developing Index (IDM) stating the status of rural area development progress. Based on the IDM of Indonesia in 2015, that $45.57 \%$ (33,592 villages) were underdeveloped villages and $18.25 \%$ (13,453 villages) were very under-developed villages out of a total of 73,709 villages in Indonesia. The Village Head's job is to lead the administration of the Village Government. This study aims to determine the effect of Self-Leadership and Achievement Motivation Training on the Performance of Village Head in Gunung Kidul Regency of Yogyakarta Province. Based on the result of hypothesis testing by using Anova Repeated Measure, where the result shows that $F=11186,541$ with significance level 0,000 ( $p<0,01)$, it proves that there is a very significant difference between pre-test, post-test, and follow-up.

Keywords: Self-leadership, achievement motivation, performance, village head, training.

\section{PENDAHULUAN}

Peraturan Menteri Desa, Pembangunan Daerah Tertinggal dan Transmigrasi (Permendes PDTT) Nomor 6 Tahun 2016 tentang Organisasi dan Tata Kerja Kementrian Desa, Pembangunan Daerah Tertinggal, dan Transmigrasi menyebutkan bahwa desa telah berkembang dalam berbagai bentuk, sehingga perlu dilindungi dan diberdayakan agar kuat, maju, mandiri, dan demokratis. Peraturan tersebut akan menciptakan landasan yang kuat dalam melaksanakan pemerintahan dan pembangunan desa menuju masyarakat yang adil, makmur, dan sejahtera. 
Berdasarkan Undang-Undang Dasar (UUD) 1945, saat ini pemerintah fokus pada upaya untuk meningkatkan pembangunan desa. Program-program yang didisain oleh pemerintah ditujukan dalam rangka membangun wilayah perdesaan. Pada kenyataannya, pemerataan pembangunan baik berupa infrastruktur maupun suprastruktur tidak merata di setiap desa sebagaimana yang tertuang dalam Indeks Desa Membangun (IDM).

IDM dikembangkan sebagai tolok ukur untuk memperkuat upaya pencapaian sasaran pembangunan desa dan kawasan perdesaan sebagaimana yang tertuang dalam Buku Rencana Pembangunan Jangka Menengah Nasional 20152019, yakni mengurangi jumlah desa tertinggal sampai dengan 500 desa dan meningkatkan jumlah desa mandiri sedikitnya 2.000 desa pada tahun 2019 . Berdasarkan Peraturan Menteri Dalam Negeri (Permendagri) Nomor 56 Tahun 2015 tentang kode dan data wilayah administrasi pemerintahan menyebutkan bahwa jumlah desa yang telah memiliki kode wilayah administrasi desa mencapai 74.754 desa, sedangkan jumlah desa berdasarkan sumber potensi desa mencapai 73.709 dari total $82.190 \mathrm{desa} /$ kelurahan/UPT (BPS, 2014). Berdasarkan indeks desa membangun (IDM), jumlah dan proporsi desa dengan status Desa Mandiri sebanyak 4,89\% (3.608 desa), Desa Maju sebanyak 0,24\% (174 desa), Desa Berkembang sebanyak 31,04\% (22.882 desa), Desa Tertinggal sebanyak 45,57\% (33.592 desa) dan Desa Sangat Tertinggal sebanyak 18,25\% (13.453 desa) (Hamidi et, al., 2015).

Penelitian ini memfokuskan kajian di wilayah Provinsi Daerah Istimewa Yogyakarta (DIY) yang berdasarkan IDM, DIY memiliki 0,694\% atau jumlah 392 desa yang terbagi atas:

1. Desa Mandiri mencapai $8,16 \%$ (32 desa)

2. Desa Maju sebanyak 34,69\% (136 desa)

3. Desa Berkembang sebanyak $44,6 \%$ (175 desa)

4. Desa Tertinggal mencapai $12,5 \%$ (49 desa)

5. Desa Sangat Tertinggal sebanyak $0 \%$.

Di sisi lain, IDM berdasarkan kabupaten, yaitu Kulon Progo mencapai 0,6429, Bantul 0,7617, Gunung Kidul 0,6638 dan Sleman 0,7367 (Hamidi et al., 2015). Berdasarkan IDM tersebut, Kabupaten Kulon Progo dan Kabupaten Gunung Kidul memiliki IDM yang paling rendah dibandingkan dengan kabupaten lainnya. Penelitian ini memfokuskan kajian pada Kabupaten Gunung Kidul. Profil demografi wilayah Kabupaten Gunung Kidul terdiri atas 18 kecamatan dan 144 desa. Selain itu, Kabupaten Gunung Kidul merupakan kabupaten terluas dengan jumlah desa yang paling banyak di Provinsi DIY.

Upaya untuk meningkatkan IDM terus dilakukan, salah satunya dengan menyiapkan perangkat desa. Penyelenggaran pemerintahan desa dipimpin oleh kepala desa. Tugas kepala desa adalah meyelenggarakan pemerintahan desa, melaksanakan pembangunan desa, pembinaan kemasyarakatan desa, dan pemberdayaan masyarakat desa. Kepala Desa adalah pemimpin tertinggi dalam pemerintahan desa. Sukrajap (2016) menyebutkan bahwa kepemimpinan transformasional memiliki dampak yang signifikan terhadap kepuasan kerja dan komitmen organisasi karyawan. Kepala desa sebagai seorang pemimpin perlu untuk mengarahkan dirinya sendiri dan anggota masyarakatnya untuk berusaha maju dan berprestasi. Untuk itu, salah satu keahlian yang penting untuk kepala desa adalah self-leadership dan memiliki motivasi berprestasi yang tinggi. Self-leadership 
merupakan faktor yang sangat berpengaruh pada cara seseorang dalam bertindak, khususnya dalam hal membuat seseorang menjadi lebih antusias dalam melakukan suatu aktivitas atau pekerjaan, memberikan komitmen terhadap kemajuan, dan kinerja khususnya dalam pemberdayaan organisasi (Manz, 1990). Sementara itu, self-leadership dapat mendorong terciptanya persepsi atas kontrol dan tanggung jawab yang positif mempengaruhi performance outcome atau kinerja (Manz, 1992 dalam Prussia et al., 1998). Menurut Huges (2012), kinerja suatu organisasi atau kelompok ditentukan oleh kinerja individu yang tergabung di dalamnya. Dalam meningkatkan kinerja kelompok, pemimpin harus memilih pengikut yang memiliki keahlian yang tepat, serta memiliki sifat pribadi yang mendukung pencapaian tujuan kinerja kelompok. Pribadi seperti ini disebut achievement orientation, yakni seorang yang termotivasi berdasarkan orientasi prestasi. Menurut Atkinson (1983), seseorang yang bekerja dengan orientasi prestasi, yaitu bertujuan dengan mengarah pada kesuksesan, akan bekerja dengan umpan balik yang cepat dan bahkan cenderung memilih tugas yang lebih sulit (yaitu tugas yang memerlukan usaha yang lebih besar, tetapi tetap dapat dikerjakan) sebagai tantangan bagi dirinya.

Kemampuan self-leadership dan adanya motivasi berprestasi yang tinggi dari seseorang diharapkan mampu berpengaruh pada peningkatan kinerjanya, sehingga dapat berpengaruh terhadap upaya peningkatan IDM di masa yang akan datang. Setiap desa perlu menyiapkan pengelolaan sumber daya manusia. Sumber daya manusia yang utama harus dikembangkan adalah Kepala Desa. Hal ini terkait dengan tugas dan tanggung jawab yang sangat penting dalam rangka membangun desa menuju desa mandiri. Oleh karena itu, perlu suatu bentuk intervensi terhadap sumber daya manusia yaitu Kepala Desa agar ia dapat memiliki keahlian self-leadership dan motivasi berprestasi yang didapatkan melalui pelatihan. Berdasarkan persoalan yang telah diuraikan dalam latar belakang di atas, maka penelitian ini menitikberatkan pada permasalahan apakah terdapat pengaruh pelatihan self-leadership dan motivasi berprestasi terhadap kinerja Kepala Desa setelah diberikan pelatihan. Dengan demikian, tujuan penelitian ini adalah untuk memperoleh bukti empiris adanya pengaruh variabel self-leadership dan motivasi berprestasi terhadap kinerja Kepala Desa sebelum dan sesudah pelaksanaan pelatihan. Ada pun hipotesis yang dibangun dalam penelitian ini adalah adanya pengaruh pelatihan self-leadership dan motivasi berpretasi terhadap kinerja Kepala Desa setelah diberikan pelatihan.

\section{TINJAUAN PUSTAKA}

\section{Pelatihan Self-Leadership dan Motivasi Berprestasi}

Pelaksanaan pelatihan yang diberikan oleh perusahaan terhadap setiap karyawannya bertujuan untuk dapat menyesuaikan keadaan-keadaan yang baru atas dasar perubahan-perubahan teknologi dan metode kerja, sehingga pelatihan akan dapat menuntut adanya perubahan sikap, tingkah laku, ketrampilan, dan pengetahuan yang dianggap dapat meningkatkan kinerja karyawan. Pelatihan adalah serangkaian aktivitas atau proses pendidikan dalam waktu singkat sebagai upaya terencana untuk meningkatkan kinerja karyawan sesuai kebutuhan jabatannya berupa perubahan secara spesifik meliputi ketrampilan pengetahuan, sikap, dan perilaku (Cummings \& Worley, 2005).

Pelatihan self-leadership adalah serangkaian aktivitas secara sistematis yang 
dirancang untuk tujuan melatihkan strategi-strategi dalam self-leadership kepada peserta. Materi dalam pelatihan ini disusun berdasarkan pengembangan konsep dasar self-leadership oleh Neck dan Manz (2007) yang tertuang dalam buku Mastering Self-Leadership, Empowering Yourself for Personal Excellence maupun hasil penelitian-penelitian terdahulu yang pernah dilakukan oleh Prussia, Anderson, dan Manz (1998). Selain itu, self-leadership juga akan diberikan pelatihan kepada kepala desa mengenai motivasi berprestasi.

\section{Hubungan Self-Leadership dan Kinerja}

Untuk mencapai kinerja yang baik menurut Byars dan Rue (1997) harus diperhatikan beberapa determinan kinerja. Menurut mereka, kinerja merupakan efek bersih dari usaha karyawan yang dimodifikasi oleh kemampuan (ability) dan persepsi peran atau tugas. Dengan demikian, kinerja pada situasi tertentu (given situation) dapat dipandang sebagai hasil interrelationship antara usaha, kemampuan, dan persepsi peran (role perception). Usaha yang dihasilkan menimbulkan motivasi untuk melaksanakan tugasnya. Kemampuan adalah karakteristik personal yang digunakan dalam melaksanakan jabatan. Persepsi terhadap peran atau tugas mengacu pada arah sejauh mana individu percaya bahwa mereka harus menyalurkan usaha mereka pada jabatan mereka. Sementara itu, penggunaan selfleadership mendorong terciptanya persepsi atas kontrol dan tanggung jawab yang secara positif akan mempengaruhi performance outcome (Manz, 1992 dalam Prussia et al, 1998). Dalam hal ini, self-leadership yang dipandang sebagai suatu agenda yang dilakukan oleh individu agar dapat menunjukkan kinerja lebih dari sekedar yang diharapkan adalah bagian dari usaha individu untuk memotivasi diri.

\section{Hubungan Motivasi Berprestasi dan Kinerja}

Berdasarkan hasil penelitian McClelland dalam Arep dan Hendri (2003), sumber motivasi paling utama adalah motivasi mencapai prestasi. Obyek penelitian tersebut adalah para eksekutif di berbagai negara. Hasilnya adalah semakin tinggi keinginan seseorang untuk berprestasi, maka hal itu menjadikan motivasi bagi dirinya yang akan berdampak positif pada kinerjanya, yaitu semakin meningkat posisi dan jabatannya. Hasil ini tidak berubah di negara berkembang, komunis, sosialis, maupun kapitalis. Oleh karena itu, dapat disimpulkan bahwa motivasi berprestasi adalah faktor terbanyak yang berkontribusi dalam peningkatan kinerja karyawan. Seseorang yang memiliki motivasi berprestasi yang tinggi cendereung menyukai situasi pekerjaan yang memiliki tanggung jawab pribadi, umpan balik, dan risiko tingkat menengah. Oleh karena itu, karyawan yang bekerja dengan motivasi yang tinggi akan memberikan dampak positif pada kinerja yang dihasilkannya. Menurut Huges (2012), kinerja suatu organisasi atau kelompok ditentukan oleh kinerja individu yang tergabung di dalamnya. Dalam meningkatkan kinerja kelompok, pemimpin harus memilih pengikut yang memiliki keahlian tepat serta memiliki sifat pribadi yang mendukung pencapaian tujuan kinerja kelompok. Pribadi seperti ini disebut achievement orientation, yakni seorang yang termotivasi berdasarkan orientasi prestasi. Menurut Atkinson (1983), seseorang yang bekerja dengan orientasi prestasi dan bertujuan mengarahkan pada kesuksesan akan bekerja dengan umpan balik dengan cepat dan bahkan cenderung memilih tugas yang lebih sulit (yaitu tugas yang memerlukan usaha yang lebih besar tetapi tetap dapat dikerjakan) sebagai tantangan bagi dirinya. 


\section{Penelitian Sebelumnya}

Pertama, penelitian Sulastri (2007) yang berjudul "Pengaruh Motivasi Berprestasi dan Disiplin terhadap Kinerja Dosen" juga memperkuat teori di atas. Hasil penelitian tersebut menunjukkan bahwa motivasi berprestasi memberikan pengaruh berarti bagi kinerja dosen, yaitu sebesar 42,2\% dibandingkan dengan disiplin kerja, yaitu sebesar 37,9\%. Kedua, penelitian yang dilakukan oleh Ike (2012) melihat pengaruh pelatihan kepemimpinan diri (self-eadership) untuk meningkatkan kepuasan kerja karyawan. Partisipan penelitian adalah karyawan non-akademik sebuah universitas swasta di Yogyakarta. Disain penelitian tersebut menggunakan the treated control group design with pretest and postest. Pada kelompok eksperimen diberikan pelatihan kepemimpinan diri (self-leadership), sedangkan pada kelompok kontrol tidak diberikan pelatihan. Hasil uji hipotesis menggunakan statistik nonparametric Mann-Whitey- $U$ yang menunjukkan tidak ada perbedaan kepuasan kerja yang signifikan antara kelompok eksperimen dan kelompok kontrol.

\section{METODE PENELITIAN}

\section{Lokasi dan Subyek Penelitian}

Lokasi penelitian ini adalah desa di Kabupaten Gunung Kidul Yogyakarta. Subyek dalam penelitian ini adalah Kepala Desa di Kabupaten Gunung Kidul Yogyakarta.

\section{Variabel Penelitian}

Variabel independen dalam penelitian ini adalah self-leadership dan motivasi berprestasi. Self-leadership diartikan sebagai salah satu faktor yang mempengaruhi penilaian diri seseorang dalam membentuk motivasi diri dan penataan diri yang sangat dibutuhkan untuk dapat berperilaku sesuai dengan kondisi ideal yang diinginkan (Manz, 1992). Motivasi berprestasi adalah motivasi yang mendorong seseorang untuk mencapai keberhasilan dalam bersaing dengan suatu ukuran keunggulan (standard of excellence) (McClelland dalam Sukadji, 2001). Variabel dependen dalam penelitian ini adalah kinerja Kepala Desa. Kinerja merupakan suatu target yang dapat dicapai seseorang atau sekelompok orang dalam suatu organisasi sesuai dengan wewenang dan tanggung jawab masing-masing dalam rangka mencapai tujuan organisasi, tidak melanggar hukum, dan sesuai dengan norma, moral, maupun etika (Salleh et al., 2011).

\section{Disain Penelitian}

Pengukuran kinerja dilakukan pada tiga tahap pengukuran sesuai dengan yang dilakukan (Neck \& Manz, 1996). Pengukuran dilakukan sebanyak tiga tahap, yaitu satu tahap sebelum pelatihan (pretest), dan dua tahap setelah dilakukan pelatihan yaitu postest dan follow up, sehingga terdapat tiga data hasil dalam penelitian ini.

\section{Analisis Data}

Analisis data dalam penelitian ini menggunakan analisis diskriptif, kuantitatif, dan kualitatif, yaitu:

a. Analisis diskriptif. Analisis diskritif dilakukan dengan menggunakan tabel distribusi frekuensi untuk melihat penyebaran data suatu variabel.

b. Analisis kuantitatif. Dalam penelitian ini, data yang diperoleh akan dianalisis menggunakan analisis kuantitatif. Alat analisis yang digunakan adalah teknik One Sample T-test, Paired Sample T-Test, dan Anova 
Repeated Measures berdasarkan pendapat Azwar (2008), yaitu untuk melihat ada tidaknya perbedaan atau peningkatan skor pada saat pre-training, post-training 1, dan post-training 2 pada masing-masing kelom-pok subyek. Hasil analisis ini juga digunakan untuk menguji hipotesis dalam penelitian ini. Alat analisis dalam penelitian ini menggunakan Software Statistica Package for Social Science (SPSS) version 23.0 for Windows. Di samping itu, hasil analisis dengan menggunakan SPSS ini diperkuat dengan mengukur evaluasi hasil pelatihan melalui indeks kepuasan peserta selama mengikuti pelatihan.

c. Analisis Data Kualitatif. Dalam penelitian ini, analisis data kualitatif digunakan melalui observasi perilaku selama kegiatan berlangsung.

\section{HASIL PENELITIAN}

\section{Validitas dan Reliabilitas Instrumen}

Pengujian alat ukur digunakan untuk mengetahui skala yang telah disiapkan oleh peneliti layak untuk digunakan. Pengujian validitas dan reliabilitas instrumen penelitian dilakukan dengan menggunakan SPSS for Windows 23.00.

a) Validitas. Berdasarkan hasil uji analisis validitas terhadap 9 butir pernyataan maka didapatkan korelasi di atas 0,3 . Hal ini menunjukkan bahwa ke-9 butir pertanyaan tersebut valid.

b) Reliabilitas. Hasil uji reliabilitas pada skala ini dinyatakan andal dengan nilai Cronbach Alpha lebih besar dari 0,6 yaitu sebesar 0,782 sehingga dapat dikatakan skala pengukuran ini reliable.

\section{Hasil Penelitian}

\section{a) Hasil uji hipotesis}

Setelah memperoleh nilai pre-test, post-test, dan follow-up dari seluruh peserta untuk menguji hipotesis dilakukan analisis parametric test menggunakan Anova Repeated Measure dan Paired Sample T-Test untuk mengetahui ada tidaknya peningkatan kinerja peserta pada saat pre-test, post-test, dan follow-up. Hipotesis yang diajukan pada penelitian ini adalah ada pengaruh pelatihan self-leadership dan motivasi berprestasi terhadap kinerja Kepala Desa. Hasil analisis menggunakan Anova Repeated Measure menunjukkan nilai $\mathrm{F}=11186,541$ dengan taraf signifikansi 0,000 $(\mathrm{p}<0,01)$. Hal itu menunjukkan bahwa ada perbedaan yang sangat signifikan antara pre-test, post-test, dan follow-up. Hasil uji hipotesis juga menggunakan Paired Sample T-Test yang dapat dilihat pada Tabel 1.

Tabel 1. Hasil Uji Paired Sample T-Test

\begin{tabular}{lccc}
\hline Hasil & N & T & Sig. \\
\hline Pretest-Postest & 15 & $-3,269$ & 0.006 \\
Postest-Follow-up & 15 & $-0,494$ & 0,629 \\
Pretest-Follow-up & 15 & $-4,217$ & 0,001 \\
\hline
\end{tabular}

Sumber: Hasil olah data (2017).

Tabel 1 membuktikan bahwa hasil uji-t (t-test) pretest ke postest menggunakan paired sample t-test menunjukkan nilai $\mathrm{t}=-3,269$ dengan taraf signifikansi 0,006 $(\mathrm{p}<0,05)$. Hal itu menunjukkan bahwa ada pengaruh yang signifikan pada pengaruh pelatihan self-leadership dan motivasi 
berprestasi terhadap kinerja Kepala Desa dari pretest ke postest. Hasil postest ke follow-up menunjukkan nilai $\mathrm{t}=-0,494$ dan taraf signifikansi $0,629(\mathrm{p}<0,05)$. Hal itu menunjukkan bahwa tidak ada pengaruh yang signifikan pada pengaruh pelatihan self-leadership dan motivasi berprestasi terhadap kinerja Kepala Desa dari postest ke follow-up. Hasil pretest ke follow-up menunjukkan nilai sebesar $\mathrm{t}=-4,217$ dan taraf signifikansi $0,001(\mathrm{p}<0,05)$. Hal ini menunjukkan ada pengaruh yang signifikan pada pengaruh pelatihan self-leadership dan motivasi berprestasi terhadap kinerja Kepala Desa antara pretest ke follow-up. Hasil rerata peningkatan skor peserta sebagaimana yang tergambar dalam Tabel 2 berikut.

Tabel 2. Hasil Rerata Skor Total

\begin{tabular}{lcc}
\hline Hasil & N & Rerata Skor \\
\hline Pretest & 15 & 30.80 \\
Postest & 15 & 34.67 \\
Follow-up & 15 & 35.07 \\
\hline
\end{tabular}

Sumber: Hasil olah data (2017).

Berdasarkan Tabel 2 di atas, penelitian ini menemukan bahwa terdapat kenaikan skor rerata total peserta dalam pelatihan. Hal ini menunjukkan adanya pengaruh pelatihan terhadap kinerja Kepala Desa.

b) Analisis hasil pengetahuan peserta

Tes pengetahuan juga diberikan kepada peserta pada awal kegiatan pelatihan dan akhir pelatihan ini berlangsung. Peserta diberikan sejumlah pertanyaan mengenai materi yang akan disampaikan oleh trainer. Hasil analisis tes pengetahuan menunjukkan nilai $\mathrm{t}=-8,359$ dengan taraf signifikansi $0,000(\mathrm{p}<0,01)$. Hal itu menunjukkan adanya peningkatan pengetahuan setelah diberikan pelatihan self-leadership dan motivasi berprestasi, artinya peserta cukup paham dengan materi yang disampaikan. Hal ini juga didukung oleh peningkatan nilai skor rerata pengetahuan dari 22,50 menjadi 50,00 sebagaimana Tabel 3 berikut.

Tabel 3. Hasil Rerata Skor Total Tes Pengetahuan

\begin{tabular}{lcc}
\hline Hasil & Butir Pertanyaan & Rerata Skor \\
\hline Pretest & 6 & 22,50 \\
Postest & 6 & 50,00 \\
\hline
\end{tabular}

Sumber: Hasil olah data (2017).

c) Hasil observasi kelas

Hasil observasi dilakukan di setiap saat untuk menangkap perilaku peserta dan trainer selama kegiatan berjalan setiap sesinya. Observasi ini dilakukan di bagian utama yaitu pembukaan, pelaksanaan, dan penutupan pelatihan.

1) Sesi Pembukaan (Pengenalan dan Peralihan). Pada tahapan ini, peneliti terlebih dahulu memperkenalkan diri dan memberitahukan maksud dan tujuan diadakannya pelatihan ini. Pada tahapan ini trainer juga memperkenalkan diri, membangun hubungan kedekatan dengan peserta, 
serta memotivasi mereka untuk dapat mengikuti kegiatan ini sampai dengan selesai.

i. Observasi peserta. Peserta belum cukup akrab dan saling berinteraksi satu sama lain. Beberapa peserta terlihat sudah saling mengenal. Pada tahap awal ini, peserta masih belum bersemangat. Namun, setelah diberikan games untuk mencairkan suasana, peserta menjadi lebih bersemangat. Selanjutnnya, peserta bersedia dan siap untuk mengikuti pelatihan setelah ditanya kesiapannya oleh pelatih.

ii. Observasi trainer. Setelah trainer memperkenalkan diri, ia mengambil alih jalannya pelatihan. Untuk membangun hubungan dan ketertarikan peserta, trainer terlebih dahulu memaparkan profil dan kompetensi trainer. Selanjutnya, ia memberikan games perkenalan untuk mencairkan suasana. Setelah itu, peserta terlihat bersemangat.

iii. Observasi kegiatan. Secara keseluruhan, kegiatan pembukaan berjalan dengan lancar. Kebersamaan dan keakraban mulai terlihat di antara para peserta.

2) Sesi Self-Leadership. Pada sesi ini, trainer memberikan materi pelatihan mengenai konsep diri, mindset, mengidentifikasi potensi kepemimpinan, dan upaya membangun kepemimpinan terhadap diri sendiri.

i. Observasi peserta. Peserta terlihat antusias mengikuti kegiatan ini dan nyaman dengan situasi dan kondisi pelatihan. Peserta terlihat aktif bertanya dan berinteraksi dengan dengan trainer dan juga kawan peserta lainnya. Peserta mengoreksi beberapa pemahaman mengenai kepemimpinan yang mereka pahami selama ini.

ii. Observasi trainer. Pada sesi ini, trainer membuka dengan mengidentifikasi pemahaman peserta mengenai konsep diri dan kepemimpinan, interaksi trainer dengan peserta mampu membangun hubungan yang baik antara trainer dengan peserta. Pada sesi ini, trainer memberikan games untuk memotivasi peserta mengikuti kegiatan dan mengaitkan games dengan materi pelatihan.

iii. Observasi kegiatan. Pada sesi ini, kegiatan berlangsung dengan baik dan lancar. Trainer menutup sesi ini dengan terlebih dahulu memberikan kesimpulan mengenai self-leadership dan memberitahukan gambaran mengenai sesi kedua tentang pentingnya motivasi berprestasi.

3) Sesi Motivasi Berprestasi. Pada sesi ini, trainer memberikan pemaparan mengenai konsep dasar kebutuhan manusia dan motivasi berprestasi yang berimplikasi pada kinerja peserta.

i. Observasi peserta. Pada awalnya, peserta kurang antusias mengikuti kegiatan. Ada beberapa peserta yang ijin pulang karena ada kegiatan lain. Namun, setelah diberikan games di awal sesi dan di tengah-tengah pelatihan, maka peserta terlihat lebih bersemangat dan mengikuti kegiatan sampai dengan selesai.

ii. Observasi trainer. Trainer dengan cermat melihat kondisi peserta yang sudah mulai kurang bersemangat mengikuti sesi ini, sehingga 
langsung memberikan games di awal dan di tengah-tengah untuk meningkatkan motivasi dan semangat peserta.

iii. Observasi kegiatan. Pada sesi ini, kegiatan berjalan dengan lancar meskipun di awal kegiatan kurang bersemgat mengikuti kegiatan. Trainer mengajak peserta untuk berinteraksi lebih dengan mengubah pola setting tempat duduk peserta menjadi bentuk $U$.

4) Sesi Penutupan. Pada sesi ini, trainer memberikan review secara keseluruhan tentang pelatihan dan juga sesi relaksasi. Pada sesi ini juga diberitahukan ada kegiatan selanjutnya. Pelatihan ini juga ditutup oleh peneliti dengan mengucapkan terima kasih atas partisipasi aktif dari setiap peserta.

i. Observasi peserta. Pada sesi penutupan ini, peserta menikmati relaksasi yang diberikan serta review materi secara keseluruhan dari awal sampai akhir oleh trainer. Peserta terlihat segar kembali setelah mendapatkan relaksasi oleh trainer.

ii. Observasi trainer. Untuk menanamkan pemahaman yang baik kepada peserta, trainer memberikan review dan relaksasi kepada peserta, sehingga peserta tampak segar kembali setelah mengikuti kegiatan selama sehari penuh dari pagi sampai sore hari.

iii. Observasi kegiatan. Secara keseluruhan, kegiatan berjalan dengan baik dan lancar. Peserta mendapatkan sesi relaksasi dan review materi dari awal sampai akhir oleh trainer. Sesi ini berakhir dan ditutup oleh peneliti dan mengucapkan terima kasih atas partisipasi serta memberikan pemberitahuan mengenai adanya kegiatan follow-up untuk melihat sejauhmana penerapan hasil pelatihan yang didapatkan.

\section{d) Hasil evaluasi proses pelatihan}

Secara umum, hasil kegiatan pelatihan self-leadership dan motivasi berprestasi dapat dilihat dari tiga perspektif, yaitu penyelenggaraan, materi pelatihan, dan trainer. Hasil evaluasi peserta terhadap pelaksanaan kegiatan pelatihan dilihat dari penyelenggaraan, materi, dan trainer memiliki nilai rerata 4,1 . Dengan demikian, secara keseluruhan peserta merasa puas terhadap pelaksanaan kegiatan pelatihan.

1) Evaluasi Penyelenggaran Pelatihan

Hasil evaluasi penyelenggaraan yang dinilai yaitu tempat, peralatan, konsumsi, alat tulis, suasana, dan ketepatan jadwal. Total rerata penyelenggaraan sebesar 3,9. Hal ini mengindikasikan bahwa peserta merasa cukup puas dengan penyelenggaran pelatihan. Faktor suasana (skor 4,5) dalam penyelenggaran kegiatan sangat membantu dalam pelaksanaan kegiatan pelatihan. Sementara itu, faktor yang paling rendah adalah ketepatan jadwal $(3,5)$. Salah satu penyebab dari keterlambatan jadwal adalah rumah peserta yang cukup jauh dari lokasi pelatihan. Di samping itu, pelaksanaan kegiatan pelatihan ini dilakukan pada hari Jum'at yang memiliki masa istirahat cukup panjang. Peserta beristirahat lebih dari jam yang dijadwalkan, sehingga jadwal untuk mengakhiri kegiatan pelatihan lebih dari jadwal yang sudah ditentukan.

2) Evaluasi Materi Pelatihan 
Ada pun hal-hal yang dinilai yaitu materi, permainan, isi handout, kegunaan handout, dan pelaksanaan proses pelatihan. Hasil rerata total didapatkan bahwa materi pelatihan membantu peserta dalam mengikuti kegiatan pelatihan ditunjukkan dengan nilai rerata 4,0 . Hal ini mengindikasikan bahwa materi yang diberikan membantu peserta selama pelatihan. Nilai tertinggi pada evaluasi ini adalah permainan dan proses pelatihan dengan skor sebesar 4,1. Peserta merasa bahwa permainan yang disajikan dalam kegiatan ini membantu peserta untuk melakukan refresh selama pelatihan berlangsung. Di samping itu, proses pelatihan juga mendukung kegiatan pelatihan.

3) Evaluasi Trainer

Hal-hal yang dinilai adalah kemampuan berkomunikasi, kemampuan menghidupkan suasana, penyampaian materi, dan metode yang digunakan. Hasil rerata total didapatkan bahwa trainer penelitian ini memiliki nilai yang tinggi yaitu 4,1 . Hal ini mengindikasikan bahwa peserta merasa puas dengan kemampuan trainer pelatihan. Dalam hal ini, trainer memiliki kemampuan yang baik dalam membawakan pelatihan. Di antara aspek-aspek penilaian tersebut, yang memiliki skor paling tinggi adalah kemampuan trainer untuk menjadi pendengar yang baik dengan nilai sebesar 4,5.

\section{PEMBAHASAN}

Berdasarkan rangkaian kegiatan pelatihan yang sudah dilakukan, secara umum, hasil yang diperoleh menunjukkan adanya pengaruh pelatihan selfleadership dan motivasi berprestasi terhadap peningkatan kinerja Kepala Desa. Hal ini menunjukkan terjadinya peningkatan kinerja Kepala Desa. Hasil ini diketahui setelah dilakukan pengukuran skala kinerja sebanyak tiga tahapan yaitu pretest, postest yang dilakukan pada saat sebelum dan sesudah penelitian berlangsung, dan satu bulan setelah pelatihan berlangsung. Intervensi berupa pelatihan menunjukkan adanya peningkatan kinerja Kepala Desa setelah pelatihan. Hal ini terlihat melalui uji hipotesis menggunakan Anova Repeated Measure yang hasilnya menunjukkan nilai $\mathrm{F}=11186,541$ dengan taraf signifikansi 0,000 $(\mathrm{p}<0,01)$. Hasil itu membuktikan ada perbedaan yang sangat signifikan antara pre-test, post-test, dan follow-up.

Dalam model Kirkpatrick (dalam Kayser \& James, 2016) menyebutkan bahwa ukuran efektifitas pelatihan dapat dilihat dari tiga level evaluasi dalam pelatihan yaitu: reaksi, pembelajaran, perilaku, dan hasil. Level pertama adalah reaksi. Tingkatan ini berkenaan dengan tingkat kepuasan peserta terhadap proses penyelengaraan pelatihan. Rata-rata hasil evaluasi penyelenggaran pelatihan sebesar 4,1 yang berarti bahwa secara keseluruhan peserta merasa puas dengan penyelenggaran pelatihan. Sementara, hasil observasi selama pelatihan secara umum berjalan dengan baik. Hal ini ditunjukkan dari respon peserta yang cukup antusias selama pelatihan. Trainer mampu mengarahkan dan memotivasi peserta untuk mengikuti pelatihan, serta berkomunikasi dengan baik. Sementara itu, pelaksanaan kegiatan juga berjalan tanpa adanya hambatan yang berarti. Level kedua adalah pembelajaran. Tingkatan ini berkorelasi dengan penambahan pengetahuan, ketrampilan, dan sikap peserta setelah penyelenggaraan program pelatihan selesai. Hal ini dapat ditunjukkan dengan adanya peningkatan pengeta- 
huan peserta sebelum dan sesudah pelatihan berlangsung, yaitu hasil analisis tes pengetahuan menunjukkan nilai $\mathrm{t}=-8,359$ dengan taraf signifikansi 0,000 $(p<0,01)$. Hasil tes tersebut menunjukkan adanya peningkatan pengetahuan setelah diberikan pelatihan dan diperkuat dengan peningkatan skor tes pengetahuan dari 22,5 menjadi 50 dari total skor 60 poin. Berdasarkan Hasil uji-t (t-test) pretest ke postest menggunakan paired sample $t$-test menunjukkan nilai $\mathrm{t}=-3,269$ dengan taraf signifikansi $0,006(\mathrm{p}<0,05)$. Hasil tes itu menunjukkan adanya pengaruh signifikan pelatihan self-leadership dan motivasi berprestasi terhadap kinerja Kepala Desa dari pretest ke postest. Hal ini juga didukung oleh adanya peningkatan skor total peserta dari pretest ke postest, yaitu peningkatan skor dari 30,80 menjadi 34,67, sehingga reaksi dan pembelajaran dalam pelatihan selfleadership dan motivasi berprestasi dapat diperoleh terhadap kinerja peserta.

Level ketiga adalah perilaku. Tingkatan ini berkorelasi pada pengetahuan, ketrampilan, dan sikap yang didapatkan selama pelatihan yang dapat diterapkan di tempat kerja. Hasil uji-t (t-test) postest ke follow-up menunjukkan nilai $\mathrm{t}=-0,494$ dan taraf signifikansi 0,629 $(\mathrm{p}<0,05)$. Hasil tes ini menunjukkan tidak adanya pengaruh signifikan pelatihan self-leadership dan motivasi berprestasi terhadap kinerja Kepala Desa dari postest ke follow-up. Meskipun secara pengujian tidak memberikan hasil yang signifikan, tetapi rata-rata skor total peserta dari postest ke follow-up menunjukkan kenaikan dari 34,67 menjadi 35,07, maka dapat disimpulkan bahwa peserta belum menerapkan sepenuhnya pengetahuan, ketrampilan, dan sikap yang didapatkan dalam pelatihan di tempat kerja mereka. Hal tersebut dikarenakan peserta tidak memperoleh intervensi tambahan berupa program tindak lanjut pelatihan, sehingga efek pelatihan tidak begitu memberikan dampak setelah pelatihan dilaksanakan. Hal ini sejalan dengan pendapat Noe (dalam Harahap, 2011) yang menyatakan bahwa efek dari pelatihan mempunyai dampak atau manfaat yang lebih besar terhadap perubahan perilaku karyawan apabila setelah pelatihan selesai dilaksanakan, diberikan program lanjutan berupa penugasan-penugasan lanjutan yang berkaitan dengan materi pelatihan tersebut. Level keempat adalah hasil. Tingkatan ini berkorelasi dengan outcome pelatihan yang berdampak kinerja organisasi secara langsung. Dalam hal ini, level keempat belum dapat dilakukan dikarenakan adanya keterbatasan waktu penelitian.

\section{KESIMPULAN DAN SARAN}

\section{Kesimpulan}

Berdasarkan hasil penelitian yang sudah dilaksanakan maka dapat disimpulkan bahwa pelatihan self-leadership dan motivasi berprestasi dapat digunakan sebagai intervensi SDM untuk meningkatkan Kinerja Kepala Desa di Gunung Kidul. Dalam menjalankan tugasnya memimpin pemerintahan desa, seorang Kepala Desa perlu meningkatkan kualitas self-leadershipnya. Di samping itu, adanya dorongan yang kuat untuk berprestasi sangat menentukan kinerja secara individu dan organisasi pemerintahan desa ke arah yang lebih baik. Hal ini berdampak pada upaya mewujudkan masyarakat desa yang sejahtera, sehingga dapat meningkatkan status kemajuan desa (IDM) menjadi lebih baik lagi.

\section{Saran}

Berdasarkan hasil penelitian tersebut, peneliti menyarankan untuk menindaklanjuti hasil ini pada penelitian berikutnya. Pertama, pelatihan self-leadership dan motivasi berprestasi memiliki pengaruh terhadap kinerja Kepala Desa. Pene- 
litian ini juga perlu dilakukan terhadap perangkat desa selain Kepala Desa. Kedua, perlunya rencana tindak lanjut dan program yang berkesinambungan terhadap pelatihan untuk dapat memaksimalkan hasil pelatihan dan pengukuran dampak pelatihan terhadap organisasi. Ketiga, penelitian ini dapat dijadikan sebagai landasan bagi penelitian berikutnya.

\section{DAFTAR REFERENSI}

Agustina, I. (2012). Pengaruh Pelatihan Kepemimpinan Diri untuk Meningkatkan Kepuasan Kerja Karyawan. Thesis. Universitas Gadjah Mada.

Arep, I. \& Hendri, T. (2003). Manajemen Motivasi. Jakarta: PT Grasindo.

Atkinson, R.L., Atkinson, R.C., \& Hilgard, E. R. (1983). Pengantar Psikologi, (Edisi ke 3). Penerjemah Agus Dharma dan Michael Adryanto. Jakarta: Erlangga.

Azwar, S. (2008). Reliabilitas dan Validitas (Ed. VIII). Yogyakarta: Pustaka Pelajar.

Badan Pusat Satistik. (2015). Statistik Daerah Istimewa Yogyakarta 2014.

Cummings, T.G. \& Worley, C.G. (2005). Organization Development and Change, (Ed. VIII). South Western Thomson.

Hamidi, H., et al., (2015). Indeks Membangun Desa. Jakarta: Kementerian Desa, Pembangunan Daerah Tertinggal, dan Transmigrasi RI.

Harahap, D.H. (2012). Pengaruh Pelatihan Supervisi terhadap Kinerja First Manager Pada Universitas X. Jurnal Psikologi, 12, 1-21.

Hughes, L.R., Robert C.G., Gordon J.C. (2012). Leadership: Memperkaya Pelajaran dari Pengalaman. Penerjemah I. Putri. Jakarta: Salemba Humanika.

Kayser, W., \& James, D. (2016). Four Level of Training Evaluation. United States: American Society of Training and Development.

Manz, C.C. (1990). The Art of Self-Leadership: Strategies for Personal Effectiveness in Your Life and Work.

. (1992). Mastering Self Leadership: Empowering your Self for Personal Excellence, (5th Edition). New Jersey: Prentice-Hall, Inc.

Neck, C.P., \& Manz, C.C. (1996). Thought Self-Leadership: The Impact of Mental Strategies Training on Employee Cognition, Behavior and Effect. Educational Psychologist, 28(2), 117-148.

Neck, C.P., \& Manz, C.C. (2007). Mastering Self Leadership, Empowering Yourself for Personal Excellence, (4th edition). New Jersey: Pearson Prentice- Hall

Permendagri RI No. 56 Tahun 2015 Tentang Kode dan Data Wilayah Administrasi Pemerintahan 
Permendes PDTT RI No. 6 Tahun 2016 Tentang Organisasi dan Tata Kerja Kementerian Desa, Pembangunan Daerah Tertinggal, dan Transmigrasi RI.

Prussia, G.E., Anderson, J.S., \& Manz, C.C. (1998). Self Leadership and Performance Outcomes: The Mediating Influence of Self-efficacy. Journal of Organizational Behaviour, 19, 523-538.

Salleh, F., Zaharah, D., Amalina, W., \& Nur, H. (2011). The Effect of Motivation on Job Performance of State Goverment Employees in Malaysia. International Journal of Humanities and Social Science, 1(4).

Sukadji. (2001). Motivasi dalam Masyarakat. Jakarta: Gramedia.

Sukrajap, M.A. (2016). Pengaruh Kepemimpinan Transformasional terhadap Kepuasan Kerja dan Komitmen Organisasi dengan Dimediasi oleh Pemberdayaan Psikologis. Jurnal Psikologi, 12, 22-45.

Sulastri, T. (2007). Pengaruh Motivasi Berprestasi dan Disiplin dengan Kinerja Dosen. Jurnal Optimal Universitas Islam 45 Bekasi, 1(1), 13-21. 